\title{
Tinjauan Yuridis Pembentukan Peraturan Perundang- Undangan Sebagai Tindak Lanjut Atas Putusan Pengujian Undang-Undang Oleh Mahkamah Konstitusi
}

\author{
Indra Wicaksono ${ }^{1}$, Rahmat Muhajir Nugroho ${ }^{2^{*}}$ \\ ${ }^{1}$ Universitas Ahmad Dahlan \\ ${ }^{2}$ Universitas Ahmad Dahlan \\ *Corresponding Author: indralaw27@gmail.com
}

\begin{tabular}{|c|c|}
\hline Histori Artikel & Abstrak \\
\hline $\begin{array}{l}\text { Masuk: } 06 \text { Mei } 2021 \\
\text { Review: } 09 \text { Mei } 2021 \\
\text { Diterima: } 21 \text { Mei } 2021 \\
\text { Terbit: } 21 \text { Mei } 2021\end{array}$ & $\begin{array}{l}\text { Tujuan penelitian ini adalah, pertama, untuk mengetahui dan } \\
\text { mengkaji secara yuridis pelaksanaan putusan uji materiil oleh } \\
\text { Mahkamah Konstitusi yang tidak berbentuk Undang- } \\
\text { Undang. Kedua, untuk mengetahui dan mengkaji pengaturan } \\
\text { ke depan mengenai pembentukan Undang-Undang yang } \\
\text { Berlaku sebagai implementasi dari putusan Mahkamah } \\
\text { Konstitusi. Penelitian ini menggunakan metode penelitian } \\
\text { dengan jenis penelitian hukum normatif. Sumber data yang } \\
\text { digunakan dalam penelitian ini adalah sumber data sekunder } \\
\text { dengan bahan hukum primer dan sekunder. Metode } \\
\text { pengumpulan data yang digunakan adalah studi pustaka dan } \\
\text { analisis dengan teknik analisis deskriptif kualitatif. } \\
\text { Berdasarkan hasil pembahasan dapat dijelaskan sebagai } \\
\text { berikut. Pertama, putusan Mahkamah Konstitusi tentang uji } \\
\text { materi yang dilaksanakan dengan bentuk hukum selain } \\
\text { undang-undang dengan menguji Undang-Undang Nomor } 12 \\
\text { Tahun } 2011 \text { tidak sesuai jika bentuk hukum selain undang- } \\
\text { undang yang mengimplementasikan atas putusan Mahkamah } \\
\text { Konstitusi tentang uji materi tersebut. Kedua, putusan } \\
\text { Mahkamah Konstitusi tentang uji materi harus dilaksanakan } \\
\text { dengan undang-undang. Maka dari itu penulis memberikan } \\
\text { rekomendasi pelaksanaan terhadap putusan Mahkamah } \\
\text { Konstitusi mengenai uji materiil tersebut, agar tidak terdapat } \\
\text { berbagai bentuk hukum pelaksanaan terhadap putusan } \\
\text { Mahkamah Konstitusi tersebut; regulasi yang tumpang tindih; } \\
\text { dan ketidakpastian hukum. } \\
\text { Kata Kunci: } \\
\text { Kata Kunci: Peradilan, Review, Peraturan Perundang- } \\
\text { undangan, Implementasi, Mahkamah Konstitusi. }\end{array}$ \\
\hline Article's History & Abstract \\
\hline $\begin{array}{l}\text { Received: } 06 \text { Mei } 2021 \\
\text { Reviewed: } 09 \text { Mei } 2021 \\
\text { Accepted: } 21 \text { Mei } 2021 \\
\text { Published: } 21 \text { Mei } 2021\end{array}$ & $\begin{array}{l}\text { The tendency of this research are, first, to find out and examine } \\
\text { juridically the implementation of judicial review decisions by the } \\
\text { Constitutional Court that are not in the forms of a Law. Second, to } \\
\text { find out and examine future arrangements regarding the formation of }\end{array}$ \\
\hline
\end{tabular}




\section{Ahmad Dahlan Legal Perspective}

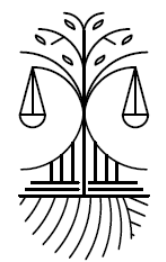

the Prevailing Laws as a implementation of Constitutional Court's decision. This research uses research methods with the type of normative legal research. Data sources used in this study are secondary data sources with primary and secondary legal materials. The data collection method used is literature study and analysis with qualitative descriptive analysis techniques. Based on the results of the discussion, it can be explained as follows. First, the Constitutional Court's decision regarding the judicial review which was implemented with a legal form other than the law legally by reviewing Law Number 12 of 2011 is inappropriate if a legal form other than the law implementing on the Constitutional Court's decision regarding the judicial review. Second, the Constitutional Court's decision regarding the judicial review should be implemented with the law. So the authors provide recommendations for implementation to the Constitutional Court's decision regarding the judicial review, so that there will not be a variety of legal forms of implementation to the Constitutional Court's decision; overlapping regulations; and legal uncertainty.

Keywords: Judicial, Review, Regulation Legislation, Implementation, Constitutional Court.

All articles are published online in http://journal2.uad.ac.id/index.php/adlp/

\section{Pendahuluan}

Sebagaimana yang disebutkan dalam Pasal 24C ayat (1) Undang-Undang Dasar Negara Republik Indonesia Tahun 1945 (UUD NRI 1945) bahwa Mahkamah Konstitusi (MK) diberikan kewenangan untuk menguji undang-undang terhadap UUD NRI 1945 yang putusannya bersifat final atau sering disebut dengan istilah judicial review. Kewenangan ini dapat dimaknai sebagai bentuk represif/penindakan, hal ini karena kewenangan judicial review oleh MK hanya dapat menguji undang-undang saja yang artinya tidak bisa menguji suatu rancangan undang-undang (Wicaksono, 2019: 94). Selain itu, sifat putusan MK ini memiliki arti bahwa putusan tersebut langsung memperoleh kekuatan hukum sejak diucapkan dan tidak ada upaya hukum yang dapat ditempuh lagi (Maulidi, 2019). Selain putusan MK yang bersifat final, putusan MK juga cenderung perlu pengaturan lebih lanjut (Martitah, 2013). Pengaturan lebih lanjut ini merupakan jenis putusan MK non selfexecuting atau putusan yang tidak dapat dilaksanakan secara langsung (Martitah, 2013). Putusan non self-executing ini memiliki arti bahwa putusan MK mengenai Pengujian Undang-Undang (PUU) membutuhkan tindak lanjut dari proses pembentukan atau perubahan suatu undang-undang (UU) yang diujikan di MK.

Putusan non self-executing yang dimiliki MK ini merupakan bentuk konsekuensi dari varian putusan MK yakni putusan MK yang menyatakan konstitusional bersyarat/ conditionally constitutional; putusan MK yang menyatakan putusan inkonstitusional 
bersyarat/ conditionally unconstitutional; putusan MK yang menyatakan penundaan keberlakuan keputusan; dan putusan MK yang menyatakan perumusan norma baru dalam putusannya (Asy'ari, 2013). Selain itu konsekuensi putusan non self-executing yaitu adanya Pasal 10 ayat (1) huruf d dan ayat (2) Undang-Undang Nomor 12 Tahun 2011 tentang Pembentukan Peraturan Perundang-undangan (UU No. 12 Tahun 2011) bahwa materi muatan UU harus berisi tindak lanjut atas putusan PUU oleh MK. Dengan demikian berdasarkan Pasal 10 ayat (1) huruf d dan ayat (2) tersebut secara tegas dan suatu keharusan bahwa putusan MK mengenai PUU merupakan bagian dari materi muatan suatu UU yang diuji di MK, dan ditindaklanjuti oleh DPR bersama Presiden sebagai pembentuk UU.

Namun faktanya dalam praktik terdapat beberapa lembaga selain DPR bersama Presiden yang menindaklanjuti putusan MK mengenai PUU. Hal ini tentu muncul kecenderungan beragamnya bentuk-bentuk hukum yang tidak sesuai dengan peraturan perundang-undangan khususnya pada UU No. 12 tahun 2011. Oleh sebab itu, beragamnya bentuk hukum yang menindaklanjuti putusan PUU oleh MK tersebut justru menjadi persoalan tersendiri lantaran tidak adanya kepastian hukum dan ketika peraturan selain dari UU sebagai tindak lanjut putusan PUU justru tidak sesuai dengan tafsiran yang terkandung dari putusannya (putusan PUU) dan/atau secara hierarkis tidak sesuai dengan derajat putusan MK (Hastuti, 2018).

Berdasarkan uraian tersebut maka, menarik untuk diteliti lebih lanjut mengenai problematika tindak lanjut atas putusan pengujian undang-undang oleh Mahkamah Konstitusi ditinjau dari Undang-Undang Nomor 12 tahun 2011 tentang Pembentukan Peraturan Perundang-Undangan. Adapun masalah yang diangkat yakni pertama, mengenai tindak lanjut putusan judicial review yang tidak berbentuk UU dan kedua, mengenai pengaturan kedepan mengenai tindak lanjut putusan MK.

\section{Metodologi}

Penelitian ini merupakan penelitian hukum normatif (Normative Legal Research), penelitian hukum normatif memiliki arti bahwa metode penelitian yang digunakan untuk menemukan suatu aturan, prinsip, doktrin hukum hal ini ditujukan untuk menemukan jawaban atas masalah hukum yang dihadapi (Marzuki, 2010). Penelitian hukum normatif ini menggunakan data sekunder yang terbagi atas bahan hukum primer, bahan hukum sekunder dan bahan hukum tersier (Soekanto \& Mamudji, 2014). Bahan hukum primer berupa putusan-putusan MK mengenai PUU yang bersifat non-self executing. Bahan hukum sekunder sebagai penunjang bahan hukum primer digali melalui buku, jurnal, hasil penelitian sebelumnya yang relevan dan internet. Cara pengumpulan data tersebut dilakukan dengan metode studi pustaka (literature research) terhadap buku, jurnal, hasil penelitian yang relevan dan 


\section{Ahmad Dahlan \\ Legal Perspective}

Volume 01, Issue 01, 2021, pp. 67-89

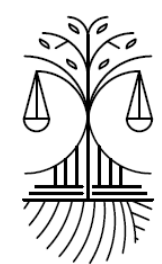

peraturan perundang-undangan. Data yang diperoleh tersebut kemudian dianalisis dengan teknik deskriptif kualitatif.

\section{Hasil and Analisis}

Tindak Lanjut Putusan Judicial Review yang Tidak Berbentuk Undang-Undang

Tindak lanjut putusan judicial review oleh MK merupakan bagian dari supremasi konstitusi. Hal ini didasarkan pada Pasal 1 ayat (2) bahwa kedaulatan rakyat dijalankan berdasarkan konstitusi (UUD NRI 1945). Oleh karena itu sangat penting sekali addressat untuk menindaklanjuti putusan MK yang sifatnya non-self executing. Namun demikian, tindak lajut putusan MK yang bersifat non-self executing ini timbul persoalan hukum. Persoalan ini muncul ketika banyak sekali addressat putusan MK yang menindaklanjuti dengan bentuk hukum selain daripada UU. Padahal, keberadaan Pasal 10 ayat (1) dan ayat (2) UU No. 12 tahun 2011 jelas menyatakan bahwa materi muatan suatu UU berisikan salah satunya tindak lanjut putusan MK yang dilakukan oleh DPR bersama Presiden. Sehingga untuk menjawab permasalahan pertama dapat diuraiakan sebagi berikut.

\section{Ragam Bentuk Hukum sebagai Tindak Lanjut Putusan MK}

Berdasarkan data yang diperoleh dari hasil pencarian melalui website dan putusan MK, penulis menemukan adanya putusan MK mengenai PUU yang bersifat non-self implementing dengan ditindaklanjuti oleh berbagai bentuk hukum selain daripada UU yang antara lain, sebagai berikut :

Tabel 1. Data Ragam Tindak Lanjut Putusan PUU MK

\begin{tabular}{|c|c|c|c|}
\hline No. & $\begin{array}{c}\text { Putusan MK } \\
\text { mengenai PUU }\end{array}$ & $\begin{array}{c}\text { Tindak Lanjut Putusan } \\
\text { PUU }\end{array}$ & Bentuk Hukum \\
\hline 1. & $\begin{array}{l}\text { Putusan MK No. 11- } \\
\text { 14-21-126 dan 136/ } \\
\text { PUU-VII/ } \\
\text { Perihal 2009 } \\
\text { Undang-Undang No. } \\
9 \text { Tahun } 2009 \text { tentang } \\
\text { Badan } \\
\text { Pendidikan. }\end{array}$ & 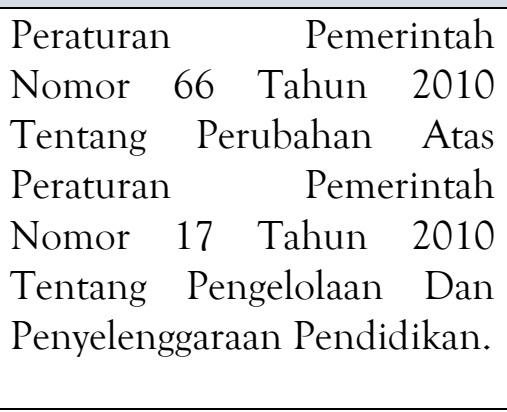 & $\begin{array}{l}\text { Peraturan } \\
\text { Pemerintah }\end{array}$ \\
\hline 2. & $\begin{array}{l}\text { Putusan MK No. 54/ } \\
\text { PUU-VI/ } \quad 2008 \\
\text { Perihal Pengujian } \\
\text { Undang-Undang No. } \\
39 \quad \text { Tahun } 2007\end{array}$ & $\begin{array}{l}\text { Peraturan Menteri Keuangan } \\
\text { Nomor 197/ PMK.07/ } 2009 \\
\text { Tentang Dasar Pembagian } \\
\text { Dana Bagi Hasil Cukai Hasil } \\
\text { Tembakau Kepada Provinsi }\end{array}$ & $\begin{array}{l}\text { Peraturan } \\
\text { Menteri }\end{array}$ \\
\hline
\end{tabular}




\begin{tabular}{|c|c|c|c|}
\hline \multirow[t]{2}{*}{ 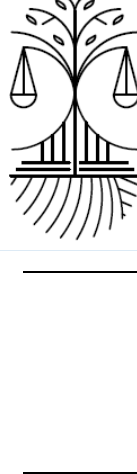 } & $\begin{array}{l}\text { Ahmad Dahlan } \\
\text { Legal Perspective } \\
\text { Volume 01, Issue 0, } 2021\end{array}$ & 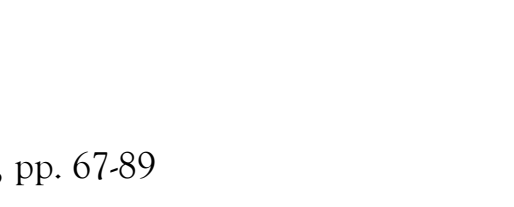 & \\
\hline & $\begin{array}{l}\text { Tentang Perubahan } \\
\text { Atas UU No. } 11 \\
\text { Tahun } 1995 \text { Tentang } \\
\text { Cukai. }\end{array}$ & $\begin{array}{l}\text { Penghasil Cukai } \begin{array}{l}\text { Dan/Atau } \\
\text { Provinsi } \\
\text { Tembakau. }\end{array} \\
\end{array}$ & \\
\hline 3. & $\begin{array}{lr}\text { Putusan MK No. 97/ } \\
\text { PUU-XIV/ } & 2016 \\
\text { Perihal Pengujian } \\
\text { Undang-Undang No. } \\
24 \quad \text { Tahun 2013 } \\
\text { Tentang Perubahan } \\
\text { Atas UU 23 Tahun } \\
2006 \quad \text { tentang } \\
\text { Administrasi } \\
\text { Kependudukan. }\end{array}$ & $\begin{array}{l}\text { Surat Edaran Menteri Dalam } \\
\text { Negeri Nomor 471.14/ } \\
\text { 10666/ Dukcapil tentang } \\
\text { penerbitan Kartu Keluarga } \\
\text { Bagi Penghayat kepercayaan } \\
\text { Tuhan Yang Maha Esa. }\end{array}$ & Surat Edaran \\
\hline 4. & $\begin{array}{l}\text { Putusan MK No. 20/ } \\
\text { PUU-XVII/ 2019 } \\
\text { Perihal Pengujian } \\
\text { Undang-Undang No. } \\
7 \quad \text { Tahun } 2017 \\
\text { Tentang Pemilihan } \\
\text { Umum. }\end{array}$ & $\begin{array}{l}\text { Peraturan Komisi Pemilihan } \\
\text { Umum Republik Indonesia } \\
\text { Nomor 11 Tahun } 2019 \\
\text { Tentang Perubahan Kedua } \\
\text { Atas Peraturan Komisi } \\
\text { Pemilihan Umum Nomor } 11 \\
\text { Tahun 2018 Tentang } \\
\text { Penyusunan Daftar Pemilih } \\
\text { Di Dalam Negeri Dalam } \\
\text { Penyelenggaraan Pemilihan } \\
\text { Umum. }\end{array}$ & $\begin{array}{l}\text { Peraturan Komisi } \\
\text { Pemilihan } \\
\text { Umum }\end{array}$ \\
\hline 5. & $\begin{array}{lr}\text { Putusan MK No. 21/ } \\
\text { PUU-XII/ } \quad 2014 \\
\text { Perihal Pengujian } \\
\text { Undang-Undang No. } \\
8 \quad \text { Tahun } 1981 \\
\text { Tentang Hukum } \\
\text { Acara Pidana. }\end{array}$ & $\begin{array}{lr}\text { Peraturan Mahkamah Agung } \\
\text { Republik Indonesia Nomor } 4 \\
\text { Tahun 2016 } & \text { Tentang } \\
\text { Larangan } & \text { Peninjauan } \\
\text { Kembali } & \text { Putusan } \\
\text { Praperadilan. } & \\
& \end{array}$ & $\begin{array}{l}\text { Peraturan } \\
\text { Mahkamah } \\
\text { Agung }\end{array}$ \\
\hline
\end{tabular}

Berdasarkan data yang diperoleh pada tabel 1 diatas menunjukan bahwa dalam praktik putusan MK mengenai PUU yang bersifat non self implementing banyak pula yang ditindaklanjuti dengan bentuk hukum selain daripada UU. Padahal, sudah jelas dinyatakan dalam Pasal 10 ayat (1) huruf d dan ayat (2) UU No. 12 tahun 2011 bahwa salah satu muatan materi UU adalah mengenai putusan MK mengenai PUU yang memerlukan tindak lanjut oleh DPR bersama Presiden. 


\section{Ahmad Dahlan \\ Legal Perspective}

Volume 01, Issue 01, 2021, pp. 67-89

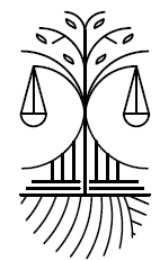

\section{Memaknai Tindak Lanjut Putusan MK}

Sebagaimana yang dinyatakan dalam Pasal 57 ayat (3) UU No. 8 tahun 2011 tentang MK bahwa putusan MK yang mengabulkan permohonan mengenai PUU wajib dimuat dalam Berita Negara Republik Indonesia dalam jangka waktu paling lama 30 hari kerja sejak putusan tersebut diucapkan. Hal ini tentu memiliki arti bahwa sebenarnya sudah semestinya putusan MK mengenai PUU tersebut sudah diundangkan dengan di umumkannya dalam Berita Negara Republik Indonesia dan langsung dapat berlaku/dilaksanakan. Namun demikian perlu kita ketahui secara teoritik bahwa putusan MK pun terbagi atas dua sifat yaitu putusan yang langsung dapat dieksekusi (self implementing) dan putusan yang sifatnya tidak dapat langsung dilaksanakan (non-self implementing). Kedua sifat tersebut, hanya putusan (tidak dapat langsung dilaksanakan atau non-self implementing) yang dapat ditindaklanjuti oleh pembentuk UU.

Sebagaimana dijelaskan pula dalam Pasal 57 ayat (2b) UU No. 8 tahun 2011 tentang MK bahwa putusan MK tidak memuat perintah kepada pembuat UU (DPR bersama Presiden). Pasal ini tentu dapat dicermati bahwa pada dasarnya MK tidak memiliki hak untuk memerintahkan kepada pembuat UU untuk menindaklanjuti putusan MK mengenai PUU. Adapun yang disebutkan dalam pasal berikutnya, yakni Pasal 59 ayat (1) dan ayat (2) UU No. 8 tahun 2011 tentang MK dimana pasal tersebut menyatakan bahwa putusan MK mengenai PUU terhadap UUD NRI 1945 disampaikan kepada DPR, Dewan Perwakilan Daerah (DPD), Presiden, dan Mahkamah Agung (MA). Jika UU yang telah diuji memerlukan perubahan maka, DPR atau Presiden segera menindaklanjuti putusan MK yang telah disampaikan oleh MK sesuai dengan peraturan perundang-undangan. Dengan demikian dari apa yang telah diuraikan dalam pasal tersebut maka putusan MK mengenai PUU, adapula yang harus ditindaklanjuti oleh pembuat UU. Artinya tidak semerta-merta putusan MK itu dapat langsung dilaksanakan. Oleh sebab itu, putusan MK tersebut tidak dapat langsung di eksekusi karena UU yang diuji harus dirubah oleh pembuat UU. Berdasarkan uraian diatas maka jelas bahwa putusan MK mengenai PUU yang salah satu sifat putusannya yakni non-self implementing merupakan putusan yang memang harus ditindaklanjuti oleh pembuat UU, karena membutuhkan perubahan terhadap norma dalam UU yang diuji.

Namun demikian disisi lain MK tidak memiliki kekuatan eksekutorial terhadap putusannya dalam hal memerintahkan pembuat UU untuk menindaklanjuti putusannya. Hal ini berdasarkan analisa penulis terhadap Pasal 59 ayat (2) UU No. 


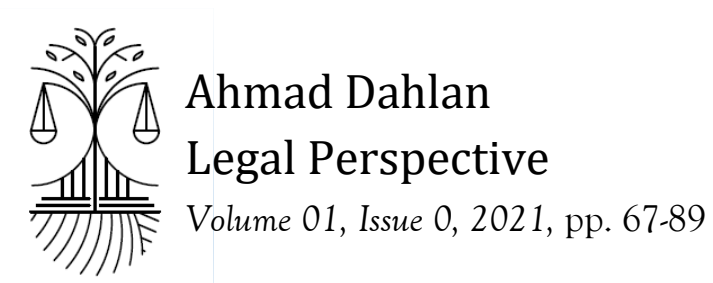

8 tahun 2011 bahwa Pasal tersebut terdapat frasa "Jika diperlukan" dan "segera" yang mana frasa tersebut memiliki maksud yang belum pasti, artinya frasa "Jika diperlukan" dapat diartikan bahwa ketika MK menguji suatu UU yang kemudian membatalkan pasal atau ayat dalam suatu UU tersebut, maka kemudian pasal atau ayat yang sudah dibatalkan tersebut tidak selalu dilakukan perubahan oleh DPR bersama Presiden. Dengan kata lain bahwa frasa "Jika diperlukan" bergantung kepada tafsir DPR bersama Presiden yang memiliki kewenangan membentuk UU, sehingga hal ini menuai ketidakjelasan dan ketidakpastian hukum. Sebagaimana dalam putusan MK Nomor 49/PUU-IX/2011 yang dalam amar putusannya menyatakan bahwa Pasal 59 ayat (2) UU No. 8 tahun 2011 tentang MK tersebut bertentangan dengan UUD NRI 1945 dan tidak mempunyai kekuatan hukum mengikat.

Selain itu frasa "segera" itu dapat diartikan oleh pembuat UU tidak harus tergantung pada waktu (cepat atau lambat). Dengan demikian dari apa yang telah diuraikan dalam pasal tersebut, maka belum adanya kepastian dan ketegasan yang jelas mengenai kapan putusan MK tersebut harus ditindaklanjuti oleh pembuat UU. Namun dengan adanya Putusan MK Nomor 49/PUU-IX/2011 diharapkan DPR bersama Presiden menindaklanjuti putusan MK mengenai PUU tanpa harus memilih putusan MK mana yang harus ditindaklanjuti.

\section{Pembentukan Peraturan Per-UU-an selain UU}

Badan pembentuk peraturan sebagai tindak lanjut atas putusan MK disebutkan dengan jelas dalam Pasal 10 ayat (2) UU No. 12 tahun 2011 bahwa tindak lanjut atas putusan MK dilakukan oleh DPR atau Presiden. Pasal ini memiliki makna bahwa putusan MK harus ditindaklanjuti oleh DPR bersama Presiden dalam bentuk UU. Dengan demikian, keberadaan pasal tersebut menutup kemungkinan terhadap lembaga lain untuk menindaklanjuti putusan MK mengenai PUU.

Selain ditinjau dari perspektif badan pembentuk untuk menindaklanjuti putusan MK, juga perlu melihat dari segi materi muatannya apakah materi muatan yang diatur dari bentuk hukum selain UU terdapat perintah untuk menindaklanjuti putusan MK atau tidak. Oleh karena itu dengan mengacu pada data yang diperoleh pada (Tabel 1) dan Pasal 7 ayat (1) dan Pasal 8 ayat(1) UU No. 12 tahun 2011 dapat diuraiakan sebagai berikut :

\section{Peraturan Pemerintah}

Peraturan dalam bentuk delegated legislation adalah peraturan perundang-undangan yang dibuat oleh lembaga diluar lembaga legislatif dan diberikan kewenangan yang 


\section{Ahmad Dahlan \\ Legal Perspective}

Volume 01, Issue 01, 2021, pp. 67-89

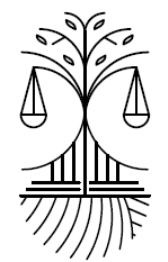

tegas oleh UU untuk membuatnya (Fathorrahman, 2018). Peraturan Pemerintah (PP) itu sendiri ditetapkan oleh Presiden untuk menjalankan UU, hal ini tertuang dalam Pasal 1 angka 5 UU No. 12 tahun 2011. Selain itu dalam Pasal 12 juga menyatakan bahwa materi muatan PP berisi materi untuk menjalankan suatu UU. Pasal tersebut memiliki arti bahwa penetapan suatu PP ditujukan untuk melaksanakan perintah UU dan sepanjang diperlukan serta tidak menyimpang/bertentangan dengan materi yang diatur dalam suatu UU yang bersangkutan. Peraturan pelaksana tersebut merupakan peraturan-peraturan yang posisinya berada dibawah UU, dimana peraturan pelaksana tersebut memiliki fungsi untuk menyelenggarakan ketentuan-ketentuan dalam suatu UU. Selain itu dalam Peraturan Presiden No. 87 tahun 2014 tentang Peraturan Pelaksanaan UndangUndang Nomor 12 Tahun 2011 tentang Pembentukan Peraturan PerundangUndangan, dalam Pasal 30 ayat (1) dan ayat (2) menyatakan bahwa dalam keadaan tertentu, PP dapat disusun diluar perencanaan program hal ini atas syarat kebutuhan UU atau putusan Mahkamah Agung (MA). Pasal tersebut menyatakan secara tegas bahwa penyusunan suatu PP dapat dilakukan dengan keberadaan suatu UU ataupun putusan MA yang merupakan bagian dari peraturan yang lebih tinggi, dengan kata lain PP disusun bukan karena keberadaan Putusan MK.

\section{Peraturan Presiden}

Sebagaimana yang tercantum dalam Pasal 1 angka 6 dan Pasal 13 UU No. 12 tahun 2011 menyatakan bahwa Peraturan Presiden (Perpres) merupakan peraturan yang ditetapkan oleh Presiden untuk menjalankan perintah peraturan perundangundangan yang derajatnya lebih tinggi atau dalam menyelenggarakan kekuasaan pemerintahan. Setidaknya dalam Perpres terdapat 3 materi muatan yang berisi, antara lain: materi yang diperintahkan oleh UU; materi untuk melaksanakan Peraturan Pemerintah; atau materi untuk melaksanakan penyelenggaraan kekuasaan pemerintahan. Oleh sebab itu Perpres dibentuk sebagai tindak lanjut atas perintah suatu UU maupun PP bukan tindak lanjut atas Putusan MK.

\section{Peraturan Daerah Provinsi dan Peraturan Daerah Kabupaten/Kota}

Peraturan Daerah Provinsi (Perda Provinsi) dan Peraturan Daerah Kabupaten/Kota (Perda Kabupaten/Kota) memiliki pengertian yang diatur dalam pasal yang sama dan angka yang berbeda, namun materi muatannya diatur dalam pasal yang sama di UU No. 12 tahun 2011. Namun demikian, hasil analisa penulis dalam UU No. 12 tahun 2011 tidak diatur dengan tegas mengenai apakah Putusan MK dapat ditindaklanjuti dengan Perda baik provinsi maupun kabupaten/kota. Dengan demikian materi muatan baik Perda Provinsi maupun Perda Kabupaten/Kota hanya diatur dalam 
Pasal 14 UU No. 12 tahun 2011 yang menyatakan bahwa materi muatan Perda Provinsi maupun Perda Kabupaten/Kota terkait dengan penyelenggaraan otonomi daerah dan tugas pembantuan serta menampung kondisi khusus daerah dan/atau sebagai tindak lanjut peraturan perundang-undangan yang lebih tinggi. Sebagaimana yang disebutkan pula dalam Pasal 32 dan Pasal 35 huruf a UU No. 12 tahun 2011 bahwa Perda Provinsi disusun dalam Program Legislasi Daerah (Prolegda) Provinsi dan penyusunan rancangan Perda Provinsi didasarkan pada perintah peraturan perundang-undangan yang lebih tinggi. Pengaturan tersebut diatas berlaku pula terhadap penyusunan Perda Kabupaten/Kota, dimana hal ini dijelaskan dalam Pasal 40 UU No. 12 tahun 2012 yang menyatakan bahwa pengaturan mengenai penyusunan Perda Provinsi berlaku pula secara mutatis mutandis terhadap penyusunan Perda Kabupaten/Kota.

\section{Peraturan Menteri}

Jenis peraturan ini disebutkan dalam Pasal 8 ayat (1) UU No. 12 tahun 2011 yang mana dalam penjelasannya menyatakan bahwa Peraturan Menteri (Permen) adalah peraturan yang ditetapkan oleh menteri yang materi muatannya berkaitan dengan penyelenggaraan urusan tertentu dalam pemerintahan. Menteri sebagai organ pemerintahan dalam arti sempit, tidak diberikan kewenangan untuk membentuk peraturan oleh Undang-Undang Nomor 39 tahun 2008 tentang Kementerian Negara. Hal tersebut memiliki arti bahwa tidak adanya kewenangan secara atribusi untuk membentuk suatu peraturan yang didapatkan Menteri dari UU yang mengaturanya, dengan kata lain Menteri dalam membentuk suatu permen hanya dapat membentuk berdasarkan kewenangan delegasi (Zahra, 2014). Dengan demikian, hasil analisa penulis bahwa permen tidak dapat menindaklanjuti Putusan MK karena Putusan MK tidak masuk dalam kualifikasi peraturan perundangundangan, selain itu dalam UU No. 12 tahun 2011 dinyatakan dengan tegas jika dasar pembentukan permen adalah dibentuk atas dasar perintah peraturan perundang-undangan yang lebih tinggi (berkualifikasi sebagai peraturan perundangundangan) dan dibentuk bukan atas dasar perintah peraturan perundang-undangan yang lebih tinggi/atas dasar kewenangan (berkualifikasi sebagai aturan kebijakan).

\section{Peraturan Mahkamah Agung}

Selain Permen, Peraturan Mahkamah Agung (Perma) pun diatur dalam Pasal 8 ayat (1) UU No. 12 tahun 2011. Namun demikian dalam UU No. 12 tahun 2011 tersebut, tidak secara rinci dijelaskan terkait dengan muatan materinya. Materi muatan Perma itu sendiri memiliki ciri khas yang salah satunya adalah berisikan ketentuan yang bersifat hukum acara (Satory \& Sibuea, 2020). Perma berlaku secara 


\section{Ahmad Dahlan \\ Legal Perspective}

Volume 01, Issue 01, 2021, pp. 67-89

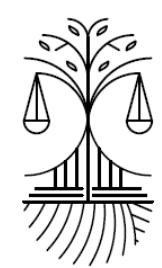

internal, hal ini memiliki arti bahwa Perma berlaku bagi penyelenggara peradilan yang ada di bawah lingkup MA termasuk peradilan umum, peradilan agama, peradilan militer, dan peradilan tata usaha negara. Adapun yang berpendapat lain bahwa Perma tidak hanya mengikat secara internal, namun dapat berlaku pula sepanjang aturan yang dibuat menyinggung lembaga negara yang lain (Shalihah, 2018). UU No. 12 tahun 2011 tidak mengatur secara rinci apa yang harus dimuat dalam produk yang dibentuk oleh MA dalam hal ini Perma termasuk tidak diaturnya apakah perma dapat menindaklanjuti Putusan MK. Namun demikian dalam Pasal 8 ayat (2) UU No. 12 tahun 2011 menyatakan bahwa peraturan yang ditetapkan oleh MA diakui keberadaannya dan mempunyai kekuatan hukum mengikat sepanjang diperintahkan oleh Peraturan yang lebih tinggi atau dibentuk berdasarkan kewenangan.

\section{Peraturan Komisi}

Negara Indonesia memiliki komisi-komisi negara, yang antara lain : KPK, Komnas HAM, KPI, KPU dan lain sebagainya. Namun demikian dari komisi-komisi tersebut terdapat perbedaan payung hukum yakni mengenai pembentukan komisi. Seperti di Indonesia ada komisi negara yang pembentukannya berdasarkan perintah UUD, Ketetapan MPR, UU. Selain itu adapula pembentuknya berasal dari Keputusan Presiden (Kepres) dan Perpres (Alamsyah \& Huda, 2013). Peraturan komisi diatur dalam Pasal 8 ayat (1) dan ayat (2) UU No. 12 tahun 2011 yang mana menyatakan bahwa peraturan yang ditetapkan oleh komisi yang setingkat dibentuk dengan UU dan peraturan komisi ini diakui keberadaannya serta memiliki kekuatan hukum mengikat sepanjang diperintahkan oleh Peraturan yang lebih tinggi. Mengacu pada Pasal 8 ayat (1) tersebut, maka tidak termasuk dengan Komisi Pemilihan Umum (KPU) karena KPU ini merupakan lembaga negara yang disebutkan dalam UUD NRI 1945 bukan hanya pada UU. Namun demikian tidak dijelaskan secara rinci mengenai tata cara pembentukan Peraturan KPU (PKPU) di UU No. 12 tahun 2011 apakah KPU dapat menindaklanjuti putusan dari MK mengenai PUU.

Selain daripada peraturan perundang-undangan yang diatur dalam UU No. 12 tahun 2011 tersebut diatas, berdasarkan data yang diperoleh dalam tabel 1 terdapat pula surat edaran (SE) yang menindaklanjuti putusan MK mengenai PUU. Padahal dalam UU No. 12 tahun 2011 beserta perubahannya pun yakni UU No. 15 Tahun 2019 tentang Perubahan atas Undang-Undang Nomor 12 Tahun 2011 tentang Pembentukan Peraturan Perundang-undangan (UU No. 15 tahun 2019) tidak menyebutkan bahwa SE merupakan bagian dari peraturan perundang-undangan. Sebagaimana pendapat Maria Farida (dalam Ali, 2018) bahwa SE tidak termasuk dalam kategori peraturan perundang-undangan. Meski demikian muncul kesan 


\section{Ahmad Dahlan Legal Perspective \\ Volume 01, Issue 0, 2021, pp. 67-89}

sebagai peraturan, namun sifatnya hanya untuk kalangan internal. Materi muatan SE biasanya menjelaskan atau membuat prosedur untuk mempermudah, atau memperjelas peraturan yang mesti dilaksanakan. SE ini sifatnya hanya memperjelas peraturan yang sudah ada, oleh karena itu SE tidak boleh menabrak peraturan perundang-undangan.

Terlepas dari uraian diatas, dalam Pasal 10 ayat (1) huruf d UU No. 12 tahun 2011 menyatakan bahwa materi muatan yang harus diatur dengan UU berisi yang salah satunya adalah tindak lanjut atas putusan MK. Perlu diketahui bahwa dalam hal PUU, putusan MK merupakan putusan yang lahir akibat adanya UU yang diuji terhadap UUD NRI 1945. Terhadap putusan MK tersebut sudah tidak tersedia lagi upaya hukum yang dapat dilakukan dengan kata lain putusan MK tidak mengadopsi upaya hukum lagi setelah perkara diputus oleh Hakim MK (Maulidi, 2018). Dengan demikian pada dasarnya isi dari putusan MK mengenai PUU adalah muatan materi dari suatu UU yang dibatalkan oleh Hakim MK, maka tepat jika Pasal 10 ayat (1) huruf d UU No. 12 tahun 2011 menyatakan salah satu muatan materi yang diatur dalam UU adalah putusan MK mengenai PUU.

Alasan lainnya adalah putusan MK mengenai PUU mengikat bagi semua orang termasuk lembaga negara. Sehingga ketika MK mengeluarkan putusan, maka dapat dikatakan sebagai negatif legislator yang putusannya bersifat erga omnes (Cristina, 2013). Dalam konteks inilah putusan MK mengenai PUU dapat dikatakan setara/sejajar derajatnya dengan UU, karena sama-sama mengikat seluruh warga negara dan lembaga negara (Suhariyanto, 2016). Namun demikian ketentuan dalam Pasal 10 ayat (1) huruf $\mathrm{d}$ tersebut dalam praktek tidak benar-benar dijalankan dengan baik.

Sehingga dengan tidak dijalankannya pasal tersebut, akan mengakibatkan dampak yang pertama, beragam bentuk hukum hasil dari tindak lanjut atas putusan MK mengenai PUU; kedua, tumpang tindih peraturan sehingga tidak dijalankannya Pasal 10 ayat (1) huruf $\mathrm{d}$ tersebut juga akan berakibat pada tumpang tindihnya peraturan sehingga aturan yang satu dengan yang lain atau peraturan yang dibawah dengan peraturan yang ada diatasnya menjadi tidak harmonis/disharmonisasi; ketiga, ketidakpastian hukum karena bentuk hukum selain UU yang dibentuk oleh addressat secara tidak langsung juga mengakibatkan ketidakpastian hukum. Hal ini karena addressat menyimpang dan tidak memperhatikan ketentuan dalam Pasal 10 ayat (1) huruf d UU No. 12 tahun 2011, sehingga pasal tersebut tidak berjalan sebagaimana mestinya. 


\section{Ahmad Dahlan \\ Legal Perspective}

Volume 01, Issue 01, 2021, pp. 67-89

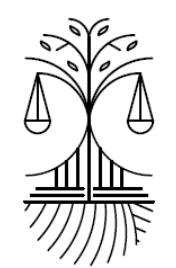

Sebenarnya, persoalannya tidak hanya kepatuhan atau ketidakpatuhan dalam menindaklanjuti putusan MK. Namun adanya keberagaman bentuk hukum dalam menindaklanjuti putusan MK ini justru menimbulkan masalah baru. Secara yuridis, dengan mengacu pada UU No. 12 tahun 2011 memang tidak dijelaskan secara eksplisit, apakah bentuk hukum selain dan dibawah UU termasuk SE dapat menindaklanjuti putusan MK mengenai PUU.

\section{Memaknai Tindak Lanjut Putusan MK Secara Yuridis}

Sebagaimana yang dinyatakan dalam Pasal 57 ayat (1) dan (2) UU No. 8 tahun 2011 tentang Perubahan atas Undang-Undang Nomor 24 Tahun 2003 tentang Mahkamah Konstitusi (UU No. 8 tahun 2011) bahwa putusan MK dalam hal pemeriksaan permohonan PUU baik itu pemeriksaan formil maupun materill yang kemudian tidak memenuhi ketentuan pembentukan UU dan bertentangan dengan UUD NRI 1945, maka UU tersebut, tidak lagi memiliki kekuatan hukum mengikat. Sementara itu putusan MK pun terbagi atas dua sifat yaitu putusan yang langsung dapat dieksekusi (self implementing) dan putusan yang sifatnya tidak dapat langsung dilaksanakan (non-self implementing). Kedua sifat tersebut, hanya putusan (tidak dapat langsung dilaksanakan atau non-self implementing) yang dapat ditindaklanjuti oleh addressat.

Padahal, sudah jelas dinyatakan dalam Pasal 57 ayat (3) UU No. 8 tahun 2011 bahwa Putusan MK yang mengabulkan Permohonan mengenai PUU wajib dimuat dalam Berita Negara Republik Indonesia dalam jangka waktu paling lama 30 hari kerja sejak putusan tersebut diucapkan. Hal ini tentu memiliki arti bahwa sebenarnya sudah semestinya putusan MK mengenai PUU tersebut sudah diundangkan dengan di umumkannya dalam Berita Negara Republik Indonesia dan langsung dapat berlaku/dilaksanakan. Sebagaimana dijelaskan pula dalam Pasal 57 ayat (2b) UU No. 8 tahun 2011 bahwa Putusan MK tidak memuat perintah kepada pembuat UU. Pasal ini tentu dapat dicermati bahwa pada dasarnya MK tidak memiliki hak untuk memerintahkan kepada pembuat UU dalam hal ini (DPR bersama Presiden) untuk menindaklanjuti putusan MK mengenai PUU. Adapun yang disebutkan dalam pasal berikutnya, yakni Pasal 59 ayat (1) dan ayat (2) UU No. 8 tahun 2011 dimana pasal tersebut menyatakan bahwa Putusan MK mengenai PUU terhadap UUD NRI 1945 disampaikan kepada DPR, Dewan Perwakilan Daerah (DPD), Presiden, dan Mahkamah Agung (MA). Jika UU yang telah diuji memerlukan perubahan maka, DPR atau Presiden segera menindaklanjuti putusan MK yang telah disampaikan oleh MK sesuai dengan peraturan perundang-undangan. Dengan demikian dari apa yang telah diuraikan dalam pasal tersebut maka putusan MK mengenai PUU, adapula yang harus ditindaklanjuti oleh pembuat UU. Artinya tidak semerta-merta putusan 


\section{Ahmad Dahlan
Legal Perspective}

MK itu dapat langsung dilaksanakan. Berdasarkan uraian diatas maka jelas bahwa putusan MK mengenai PUU yang salah satu sifat putusannya yakni non-self implementing merupakan putusan yang memang harus ditindaklanjuti oleh pembentuk UU, karena membutuhkan perubahan terhadap norma dalam UU yang diuji.

Namun demikian disisi lain MK tidak memiliki kekuatan eksekutorial terhadap putusannya dalam hal memerintahkan pembuat UU untuk menindaklanjuti putusannya. Hal ini berdasarkan analisa penulis terhadap Pasal 59 ayat (2) UU No. 8 tahun 2011 bahwa Pasal tersebut terdapat frasa "Jika diperlukan" dan "segera" yang mana frasa tersebut memiliki maksud yang belum pasti, artinya frasa "Jika diperlukan" dapat diartikan bahwa ketika MK menguji suatu UU yang kemudian membatalkan pasal atau ayat dalam suatu UU tersebut, maka kemudian pasal atau ayat yang sudah dibatalkan tersebut tidak selalu dilakukan perubahan oleh DPR bersama Presiden. Dengan kata lain bahwa frasa "Jika diperlukan" bergantung kepada tafsir DPR bersama Presiden yang memiliki kewenangan membentuk UU, sehingga hal ini menuai ketidakjelasan dan ketidakpastian hukum. Sebagaimana dalam putusan MK Nomor 49/PUU-IX/2011 yang dalam amar putusannya menyatakan bahwa Pasal 59 ayat (2) UU No. 8 tahun 2011 tersbut bertentangan dengan UUD NRI 1945 dan tidak mempunyai kekuatan hukum mengikat. Kemudian frasa "segera" itu dapat diartikan oleh pembuat UU tidak harus tergantung pada waktu (cepat atau lambat). Dengan demikian dari apa yang telah diuraikan dalam pasal tersebut, maka belum adanya kepastian dan ketegasan yang jelas mengenai kapan putusan MK tersebut harus ditindaklanjuti oleh pembentuk UU. Namun dengan adanya Putusan MK Nomor 49/PUU-IX/2011 diharapkan DPR bersama Presiden menindaklanjuti putusan MK mengenai PUU tanpa harus memilih putusan MK mana yang harus ditindaklanjuti.

\section{Pengaturan Kedepan Mengenai Tindak Lanjut Putusan MK}

Berdasarkan uraian diatas dari hasil telaah secara yuridis, jelas ditegaskan dalam Pasal 10 ayat (1) huruf d UU No. 12 tahun 2011 bahwa tindak lanjut putusan MK hanya dapat ditindaklanjuti oleh DPR bersama Presiden dengan bentuk UU. Namun demikian dalam praktek Pasal 10 ayat (1) huruf d tersebut masih kerap disimpangi oleh adressat dengan menindaklanjuti Putusan MK dengan bentuk hukum selain UU. Sehingga penulis merekomendasikan dengan memberikan konstruksi pengaturan kedepan megenai tindak lanjut Putusan MK, yang diuraiakan sebagai berikut.

Menegakan Prinsip Check and Balances 


\section{Ahmad Dahlan \\ Legal Perspective}

Volume 01, Issue 01, 2021, pp. 67-89

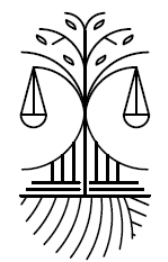

UUD NRI 1945 sebagai konstitusi Negara Indonesia mencerminkan prinsip negara hukum (rechtsstaats). Hal ini tercermin pada Pasal 1 ayat (3) UUD NRI 1945 yang menyatakan bahwa Negara Indonesia yang merupakan negara hukum membawa konsekuensi bahwa segala tindakan dari setiap lapisan elemen masyarakat harus mematuhi peraturan yang berlaku. Terlebih pula para pemegang kekuasaan harus patuh terhadap hukum sebagaimana adagium Lord Acton yang menyatakan bahwa "Power tends to corrupt, and absolute power corrupt absolutely" yang memiliki arti bahwa kekuasaan itu cenderung untuk korupsi dan kekuasaan yang absolut cenderung korupsi absolut (Djaja, 2010: 1). Adagium tersebut tidak hanya mencakup korupsi uang namun menggambarkan penguasa yang ingin menyalahgunakan kekuasaannya (korupsi politik atau kebijakan) (Bhakti, 2010).

Sebagaimana yang diungkapkan oleh Asshiddiqie (dalam Najih, 2014) bahwa salah satu prinsip negara hukum modern adalah adanya pembatasan kekuasaan berdasarkan konstitusi (Undang-Undang Dasar). Oleh sebab itu kewenganan judicial review lembaga peradilan MK yang tertuang dalam Pasal 24C UUD NRI 1945 merupakan bagian dari pembatasan kekuasaan dari DPR dan Presiden, sehingga secara tidak langsung keberadaanya merupakan penerapan prinsip check and balances.

Adapun gambaran dalam penerapan sistem check and balances yakni pembuat UU sebagaimana dinyatakan dalam Pasal 20 UUD NRI 1945 bahwa DPR memegang kekuasan membentuk UU dan dibahas bersama Presiden untuk mendapat persetujuan bersama. Mahfud MD (dalam Salam, 2015) menyatakan bahwa hukum (UU) itu tidak terlepas dari pengaruh politik dalam perumusannya bahkan nampak lebih dominan politik didalamnya sehingga sulit menemukan bentuk hukum yang netral dari pengaruh politik. Dengan demikian, warga negara yang hak konstitusionalnya dirugikan oleh suatu UU tersebut, maka dapat mengajukan permohonan pengujiannya ke MK yang diberikan kewenangan untuk melakukan judicial review. Salah satu sifat putusan yang dimiliki MK pun (non-self implementing) membawa konsekuensi kepada pembuat UU untuk memperbaiki suatu UU yang bertentangan dengan UUD.

Berdasarkan uraian tersebut diatas maka jelas bahwa kewenangan judicial review MK merupakan bagian dari penerapan sistem check and balances, yang mana kewenangan tersebut kemudian menghasilkan putusan yang salah satu sifatnya adalah non-self implementing atau putusan yang harus ditindaklanjuti oleh pembuat UU. Sifat putusan ini ditujukan supaya UU yang dinyatakan bertentangan dengan UUD NRI 1945 dapat diperbaharui oleh pembentuk UU (DPR bersama Presiden) sebagai badan legislasi. 


\section{Ahmad Dahlan}

Legal Perspective

Volume 01, Issue 0, 2021, pp. 67-89

Pengaturan dan Problematika Tindak Lanjut Putusan MK Berdasarkan Hukum Positif Indonesia (ius constitutum)

Tindak lanjut mengenai putusan MK setidaknya diatur dalam 2 (dua) UU. Pertama, UU No. 8 tahun 2011; dan kedua, UU No. 12 tahun 2011. Melalui UU No. 8 tahun 2011, lembaga peradilan MK dalam putusannya mengenai PUU terhadap UUD NRI 1945 disampaikan kepada DPR, Dewan Perwakilan Daerah, Presiden, dan MA. Kemudian jika diperlukan terhadap UU yang telah diuji DPR atau Presiden segera menindaklanjuti putusan MK tersebut sebagaimana yang disebutkan dalam Pasal 59 ayat (2). Namun setelah diputusnya putusan MK Nomor 49/PUU-IX/2011, Pasal 59 ayat (2) tersebut tindak mempunyai kekuatan hukum mengikat. Hal ini dikarenakan menurut MK pasal tersebut tidak sesuai dengan tujuan pembentukan MK sebagai pelindung hak konstitusional warga negara.

Kedua, melalui UU No. 12 tahun 2011 yang disebutkan dalam Pasal 10 ayat (1) menyatakan bahwa muatan materi dari suatu UU salah satunya berisikan tindak lanjut atas putusan MK. Kemudian pada ayat (2) menyatakan bahwa tindak lanjut atas putusan MK dilakukan oleh DPR bersama Presiden. Seperti yang kita ketahui bahwa dalam bab sebelumnya dibahas mengenai putusan MK yang sifat putusannya tidak dapat langsung dilaksanakan. Maka demikian isi norma yang diatur dalam Pasal 10 ayat (1) huruf $\mathrm{d}$ tersebut merupakan putusan MK yang tidak dapat langsung dilaksanakan sehingga memerlukan tindak lanjut.

Berdasarkan uraian diatas, maka jelas bahwa wadah atas tindak lanjut putusan MK harus dalam bentuk UU, yang mana jenis peraturan ini pembentukannya merupakan kewenangan dari DPR bersama Presiden sebagaimana yang termaktub dalam Pasal 65 ayat (1) UU No. 12 tahun 2011 bahwa Pembahasan RUU dilakukan oleh DPR bersama Presiden atau menteri yang ditugasi. Sehingga secara yuridis terbukti bahwa peraturan selain daripada UU yang menindaklanjuti putusan MK mengenai PUU tidaklah tepat, hal ini karena keberadaan dari Pasal 10 ayat (1) dan ayat (2) UU No. 12 tahun 2011 dan tidak diaturnya secara explisit atau tegas mengenai pembentukan peraturan atas tindak lanjut putusan MK selain UU dalam peraturan yang terkait, khususnya UU No. 12 tahun 2011.

Mengenai problematika tindak lanjut putusan MK berdasarkan hukum positif Indonesia baik itu yang diatur dalam UU No. 8 tahun 2011 tentang MK maupun UU No. 12 tahun 2011 tentang pembentukan peraturan perundang-undangan beserta perubahannya, masih terdapat beberapa permasalahan terkait dengan hal 


\section{Ahmad Dahlan \\ Legal Perspective}

Volume 01, Issue 01, 2021, pp. 67-89

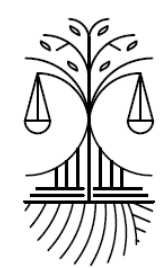

tersebut. Permasalahan terkait dengan tindak lanjut putusan MK tersebut, setidaknya terdapat 2 aspek, yakni :

1. Proses legislasi UU membutuhkan waktu yang lama

Pembentukan suatu UU di Indonesia dilakukan oleh DPR bersama Presiden. Namun demikian UU dalam pembentukannya membutuhkan waktu yang lama dengan prosedur yang panjang (Fadli, 2018). UU No. 12 tahun 2011 menentukan tahap pembentukan UU dimulai dari tahap perencanaan, penyusunan, pembahasan, pengesahan atau penetapan, dan pengundangan. Setelah adanya perubahan UU No. 12 tahun 2011 yang dirubah dalam UU No. 15 tahun 2019 proses pembentukan UU diatur dalam pasal 16 sampai 23, pasal 43 sampai 51 dan pasal 65 sampai 74 (Dariyanto, 2018).

Berdasarkan ketentuan tersebut, maka UU dapat dibentuk oleh DPR bersama Presiden. Namun demikian memang tidak menutup kemungkinan prosedur tersebut justru menghambat lahirnya UU sebagai alat kontrol dalam masyarakat. Karena proses pembentukan UU itu sendiri membutuhkan waktu yang lama.

\section{Kebutuhan hukum addressat yang dinamis}

Sebagaimana yang kita ketahui bahwa suatu UU tertentu memiliki alamatnya masingmasing (addressat). Sebagai contoh Undang-Undang Nomor 48 Tahun 2009 tentang Kekuasaan Kehakiman yang memiliki lembaga menjadi addressat yaitu MA, MK, dan KY. Dengan demikian setiap addressat akan terdampak jika UU tersebut diuji dan kemudian pasal dan/atau ayatnya dibatalkan oleh MK. Sebagai gambaran misalnya, MK menguji dan kemudian membatalkan suatu UU yang berkaitan dengan tahapan hukum acara dibawah lingkup peradilan MA, kemudian MA menindaklanjuti putusan MK dengan bentuk hukum (Perma) tanpa harus menunggu perubahan UU yang diuji. Hal ini, dikarenakan proses perubahan UU yang lama dan waktunya bergantung pada keinginan DPR bersama Presiden dalam merubahnya.

Berdasarkan uraian tersebut maka aspek mengenai kebutuhan hukum addressat yang dinamis perlu kita pertimbangkan supaya kebutuhan hukum dapat mengikuti perkembangan masyarakat terkhusus pada masing-masing addressat yang dinamis.

Kerangka Pengaturan Ideal Pembentukan Peraturan Perundang-Undangan sebagai Tindak Lanjut Putusan MK

Tindak lanjut putusan MK mengenai PUU menuai beberapa persoalan, seperti yang sudah disampaikan diatas bahwa setidaknya penulis mendapatkan 2 persoalan, yaitu pertama, mengenai putusan $\mathrm{MK}$ yang ditindaklanjuti oleh masing-masing addressat 


\section{Ahmad Dahlan Legal Perspective \\ Volume 01, Issue 0, 2021, pp. 67-89}

dengan berbagai bentuk hukum. Kemudian kedua, mengenai kurang efektifnya putusan MK yang ditindaklanjuti dengan UU, karena membutuhkan waktu yang lama dalam proses pembentukannya.

Oleh sebab itu, perlu kerangka pengaturan kedepan yang ideal sebagai dasar yang mengatur mengenai tindak lanjut putusan PUU oleh MK. Hal ini supaya dapat terwujudnya tujuan pembentukan MK sebagai pengawal konstitusi (Sudirman, 2016). Maka penulis memberikan kerangka pengaturan kedepan yang ideal untuk mengatur mengenai tindak lanjut putusan PUU oleh MK. Kerangka yang efektif mengenai tindak lanjut putusan MK mengenai PUU sangat diperlukan, mengingat bahwa Indonesia merupakan negara yang berdasarkan hukum sehingga kepastian hukum merupakan instrumen yang harus ditegakan dalam negara hukum itu sendiri.

Berdasarkan uraian diatas, maka kerangka yang diajukan adalah pertama, diperbolehkannya bentuk hukum selain UU menindaklanjuti putusan MK dalam rangka mengisi kekosongan hukum (rechtvacum); dan kedua, tetap diaturnya UU sebagai tindak lanjut putusan MK mengenai PUU. Dua kerangka tersebut akan dijabarkan, sebagai berikut :

1. Tindak lanjut putusan MK dengan bentuk hukum selain UU dalam rangka mengisi kekosongan hukum

Tindak lanjut putusan MK dalam bentuk hukum selain UU muncul permasalahan karena tidak diaturnya secara eksplisit dalam suatu aturan. Namun disisi lain, tindak lanjut dalam bentuk hukum selain UU ini sangat dibutuhkan ketika kebutuhan hukum sangat mendesak, hal ini tentu karena tidak mungkin untuk menunggu proses legislasi yang memakan waktu lama. Oleh karena itu addressat putusan MK diperbolehkan untuk menindaklanjuti putusan MK mengenai PUU. Namun demikian hal ini harus didasarkan pada pertama, kebutuhan hukum yang mendesak $\&$ untuk mengisi kekosongan hukum. Kedua, patuh terhadap putusan MK mengenai PUU dan ketiga keberlakukan aturan yang sementara.

Alasan pertama, memiliki arti yang harus dijelaskan bahwa ketika addressat putusan MK akan membentuk peraturan sebagai tindak lanjut putusan MK, maka harus berdasarkan kebutuhan hukum yang sangat mendesak dan bersifat sementara. Kebutuhan hukum mendesak ini harus ditafsirkan sebagaimana yang tercantum dalam Pasal 23 ayat (2) UU No. 12 tahun 2011 bahwa tindak lanjut putusan MK selain UU ditujukan untuk mengatasi keadaan luar biasa, keadaan konflik, atau bencana alam dan keadaan tertentu lainnya yang memastikan adanya urgensi nasional. 


\section{Ahmad Dahlan \\ Legal Perspective}

Volume 01, Issue 01, 2021, pp. 67-89

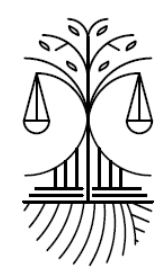

Sebagai contoh Putusan MK No. 20/PUU-XVII/2019 perihal PUU dengan UndangUndang No. 7 tahun 2017 tentang pemilihan umum terhadap UUD NRI 1945. Putusan tersebut dalam salah satu amar putusannya menyatakan bahwa frasa "kartu tanda penduduk elektronik" dalam Pasal 348 ayat (9) Undang-Undang No. 7 Tahun 2017 tentang Pemilihan Umum bertentangan dengan UUD NRI 1945 dan tidak mempunyai kekuatan hukum mengikat secara bersyarat sepanjang tidak dimaknai "termasuk pula surat keterangan perekaman kartu tanda penduduk elektronik yang dikeluarkan oleh dinas kependudukan dan catatan sipil atau instansi lain yang sejenisnya yang memiliki kewenangan untuk itu”. Padahal pada saat itu, pemilihan Presiden dan pemilihan Legislatif akan diselenggarakan pada tanggal 17 April 2019 secara serentak. Oleh sebab itu, karena kebutuhan hukum yang mendesak, akhirnya KPU sebagai penyelenggara pemilu menindaklanjuti Putusan MK tersebut dengan mengeluarkan PKPU No. 11 tahun 2019 tentang Penyusunan Daftar Pemilih Di Dalam Negeri Dalam Penyelenggaraan Pemilihan Umum pada tanggal 5 April 2019.

Alasan kedua, memiliki arti bahwa addressat dalam membentuk peraturan yang menindaklanjuti putusan MK (selain UU) harus memperhatikan betul apa isi substansi dalam amar putusan MK mengenai PUU. Hal ini tidak lain ditujukan supaya aturan selaras dengan aturan yang ada diatasnya dan untuk menjamin konstitusional suatu peraturan. Dalam kaitan tersebut, Bede Harris (dalam Soeroso, 2013) menyatakan bahwa faktor yang menentukan apakah dalam praktik ajaran mengenai konstitusionalisme diikuti atau tidak, terletak pada jawaban atas pertanyaan apakah pemerintah menghormati dan melaksanakan putusan pengadilan atau tidak.

Alasan ketiga, berdasarkan uraian diatas, maka perlu digaris bawahi pula mengenai sifat sementara dari bentuk hukum selain UU yang menindaklanjuti putusan MK. Sifat sementara itu memiliki arti bahwa ketika putusan MK mengenai PUU sudah ditindaklanjuti oleh UU maka bentuk hukum selain UU tersebut dicabut dan dinyatakan tidak berlaku lagi.

2. Tetap diaturnya tindak lanjut putusan MK dengan bentuk hukum UU

Tetap diaturnya tindak lanjut putusan MK dengan UU beranjak dari uraian sebelumnya bahwa kedudukan putusan MK setara dengan undag-undang hal ini karena akibat hukumnya mengikat semua warga negara termasuk lembaga negara (erga omnes). Disisi lain materi muatan yang diuji di MK adalah muatan materi dari UU. oleh sebab itu sudah seyogyanya bahwa putusan MK ditindaklanjuti oleh UU. 


\section{Ahmad Dahlan
Legal Perspective}

Kerangka ini memiliki kaitan yang erat dengan kerangka mengenai tindak lanjut putusan MK dengan bentuk hukum selain UU sebagaimana yang sudah diuraikan diatas. Tindak lanjut putusan MK dengan UU ini bukan merupakan tindakan alternatif. Beda halnya dengan kerangka sebelumnya mengenai tindak lanjut putusan MK dengan bentuk hukum selain UU yang merupakan tindakan alternatif dalam pembentukan peraturan perundang-undangan.

Tetap diaturnya muatan meteri UU berisi tindak lanjut putusan $\mathrm{MK}$, supaya memiliki korelasi dengan kerangka sebelumnya (tindak lanjut dengan bentuk hukum selain UU) maka perlu adanya penegasan mengenai ketentuan yang menyatakan dicabutnya dan tidak berlakuknya peraturan dibawah UU mengenai tindak lanjut putusan MK yang ditindaklanjuti oleh UU tersebut.

Sebagaimana yang dijelaskan dalam Lampiran II UU No. 12 tahun 2011 bahwa ketentuan penutup merupakan materi wajib batang tubuh dalam pembentukan peraturan perundang-undangan. Pada umumnya ketentuan penutup memuat ketentuan mengenai: 1) penunjukan organ atau alat kelengkapan yang melaksanakan Peraturan Perundang-undangan; 2) nama singkat Peraturan Perundang-undangan; 3) status Peraturan Perundang-undangan yang sudah ada; dan 4) saat mulai berlaku Peraturan Perundang-undangan.

Berdasarkan uraian tersebut maka, ketika DPR bersama Presiden sudah mengeluarkan UU sebagai hasil tindak lanjut putusan MK, maka dalam ketentuan penutup UU tersebut harus menyatakan "pada saat undang-undang ini mulai berlaku, maka bentuk hukum selain undang-undang yang menindaklanjuti putusan MK (nomor), dicabut dan dinyatakan tidak berlaku”. Dengan demikian aturan selain UU yang menindaklanjuti putusan MK tidak berlaku lagi dan addressat putusan MK dapat membuat aturan dengan mengacu pada UU yang sudah menindaklanjuti suatu putusan MK tersebut.

Kerangka yang diuraikan diatas menitikberatkan pada perubahan/revisi UU No. 12 tahun 2011 beserta perubahannya yaitu UU No. 15 tahun 2019 dengan menambahkan norma pada pasal dan/atau ayat sebagaimana yang sudah diuraikan penulis diatas. Hal ini perlu dilakukan mengingat negara Indonesia merupakan negara hukum, maka segala tindakan yang akan dilakukan harus berdasar atau berasalkan hukum. Uraian diatas dengan diaturnya kerangka tindak lanjut yang diajukan oleh penulis, diharapkan dapat memenuhi rasa keadilan, kemanfaatan dan kepastian hukum.

Kesimpulan 


\section{Ahmad Dahlan \\ Legal Perspective}

Volume 01, Issue 01, 2021, pp. 67-89

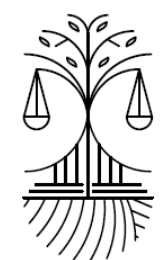

Tindak lanjut putusan MK secara tegas sudah diatur dalam Pasal 10 ayat (1) huruf d UU No. 12 tahun 2011 tentang Pembentukan Peraturan Perundang-undangan yang menyatakan bahwa materi muatan undang-udang adalah tindak lanjut dari putusan MK mengenai PUU. Namun dalam praktek putusan MK mengenai PUU ditindaklanjuti dengan bentuk hukum selain UU. Bentuk hukum tersebut antara lain dapat berupa PP, PERMEN, PKPU, PERMA dan SE. Secara yuridis, tindak lanjut putusan MK dengan bentuk hukum selain UU, dengan mengacu pada UU No. 12 tahun 2011 memang tidak dijelaskan secara jelas dan tegas. Dengan demikian ketika Pasal 10 ayat (1) huruf d UU No. 12 tahun 2011 disimpangi, maka akan berimplikasi pada a. ragamnya bentuk hukum sebagai tindak lanjut putusan MK; b. tumpang tindih peraturan; dan c. ketidakpastian hukum. Oleh karena itu, kurang tepat jika bentuk hukum selain dan dibawah UU termasuk SE dapat menindaklanjuti putusan MK mengenai PUU.

Tindak lanjut Putusan MK mengenai PUU merupakan bagian dari implementasi adanya sistem check and balances. Keberadaan Pasal 59 ayat (2) UU No. 8 tahun 2011 dan Pasal 10 ayat (1) huruf d UU No. 12 tahun 2011 membawa konsekuensi bahwa tindak lanjut putusan MK, seharusnya ditindaklanjuti oleh DPR bersama Presiden dengan bentuk hukum UU. Namun tindak lanjut putusan MK dalam bentuk UU justru menuai problematika yang antara lain, yakni : pertama, proses legislasi UU membutuhkan waktu yang lama; dan kedua, kebutuhan hukum addressat dan masyarakat yang dinamis. Oleh karena itu, diperlukan pengaturan yang ideal mengenai tindak lanjut putusan MK yakni dengan pertama, diperbolehkannya bentuk hukum selain UU menindaklanjuti putusan MK dalam rangka mengisi kekosongan hukum yang sifatnya alternatif \& sementara; dan kedua, tetap diaturnya UU sebagai tindak lanjut putusan MK mengenai PUU sekaligus mencabut dan menyatakan tidak berlaku bentuk hukum selain UU yang menindaklanjuti putusan MK yang dimaksud. Dengan demikian kedua kerangka tersebut harus memiliki korelasi satu sama lain.

Referensi

Buku

Christina, Dri Utari., \& Hasani, Ismail. (2013). Masa Depan Mahkamah Konstitusi RI Naskah Konferensi Mahkamah Konstitusi Dan Pemajuan Hak Konstitusional Warga. Jakarta: Pustaka Masyarakat Setara.

Djaja, Ermansjah. (2010). Memberantas Korupsi Bersama KPK. Edisi Kedua. Jakarta: Sinar Grafika. 


\section{Ahmad Dahlan Legal Perspective \\ Volume 01, Issue 0, 2021, pp. 67-89}

Martitah. (2013). MK: dari Negative Legislature ke Positive Legislature?. Jakarta: Konstitusi Press.

Najih, Mokhammad. (2014). Politik Hukum Pidana Konsepsi Pembaharuan Hukum Pidana Dalam Cita Negara Hukum. Malang: Setara Press.

Soekanto, Soerjono., \& Mamudji, Sri. (2014). Penelitian Hukum Normatif Suatu Tinjauan Singkat. Jakarta: PT. Raja Grafindo Persada.

Jurnal

Agus Maulidui, M. (2018). Problematika Hukum Implementasi Putusan Final dan Mengikat Mahkamah Konstitusi Perspektif Negara Hukum. Jurnal Hukum Ius Quia Iustum, 24(4), 535-557. Retrieved from https://doi.org/10.20885/iustum.vol24.iss4.art2 535-557

Agus Maulidi, M. (2019). Menyoal Kekuatan Eksekutorial Putusan Final dan Mengikat Mahkamah Konstitusi. Jurnal Konstitusi, 16(2), 339-362. Retrieved from $\underline{\text { https://doi.org/10.31078/jk1627 }}$

Alamsyah, Bunyamin., \& Huda, Uu Nurul. (2013). Politik Hukum Pelembagaan Komisi-Komisi Negara Dalam Sistem Ketatanegaraan Indonesia. Jurnal Hukum Peradilan, 2(1), 85-108. Retrieved from http://dx.doi.org/10.25216/jhp.2.1.2013.85-108

Fadli, Muhammad. (2018). Pembentukan Undang-Undang Yang Mengikuti Perkembangan Masyarakat. Jurnal Legislasi Indonesia, 15(1), 51-61. Retrieved from_https://ejurnal.peraturan.go.id/index.php/jli/article/view/12

Fathorrahman, F. (2018). Peraturan Delegasi dalam Sistem Peraturan PerundangUndangan Indonesia. Jurnal Rechtens, 7(2), 193-212. Retrieved from http://ejurnal.uij.ac.id/index.php/REC/article/view/376

Hastuti, Proborini. (2018). Pemberian Kewenangan Judicial Order Kepada MK Dalam Pengujian Undang-Undang Terhadap Undang Undang Dasar. Supremasi Hukum. 7(1), 49-69. Retrieved from http://ejournal.uinsuka.ac.id/syariah/Supremasi/article/view/2029/1505

Salam, Abdus. (2015). Pengaruh Politik Dalam Pembentukan Hukum Di Indonesia. Jurnal Pemikiran Hukum Islam, 14(2), 120-131. Retrieved from http://dx.doi.org/10.21093/mj.v14i2.341

Satory, Agus., \& Sibuea, Hotma. (2020). Problematika Kedudukan Dan Pengujian Peraturan Mahkamah Agung Secara Materiil Sebagai Peraturan PerundangUndangan. Palar-Pakuan Law Review, 6(1), 1-27. Retrieved from https://doi.org/10.33751/palar.v6i1.1831 


\section{Ahmad Dahlan \\ Legal Perspective}

Volume 01, Issue 01, 2021, pp. 67-89

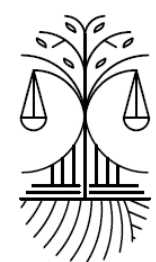

Soeroso, Fajar Laksono. (2013). "Pembangkangan" Terhadap Putusan Mahkamah Konstitusi. Jurnal Yudisial, 6(3), 227-249. Retrieved from http://dx.doi.org/10.29123/jy.v6i3.100

Sudirman, Sudirman. (2016). Memurnikan Kewenangan Mahkamah Konstitusi Sebagai Lembaga Pengawal Konstitusi (The Guardian Of The Constitution). Jurnal Ilmiah Pendidikan Pancasila dan Kewarganegaraan, 1(1), 4855. Retrieved from http://dx.doi.org/10.17977/um019v1i12016p048

Suhariyanto, Budi. (2016). Masalah Eksekutabilitas Putusan Mahkamah Konstitusi oleh Mahkamah Agung. Jurnal Konstitusi, 13(1), 171-190. Retrieved from https://doi.org/10.31078/jk1318

Syukri, Asy'ari., Hilipito, Meyrinda Rahmawaty., Ali, Mohammad Mahrus. (2013). Model dan Implementasi Putusan MK dalam Pengujian Undang-Undang (Studi Putusan Tahun 2003-2012). Jurnal Konstitusi, 10(4), 675-708. Retrieved from http://dx.doi.org/10.31078/jk\%x

Wicaksono, Indra. (2019). Optimalisasi Peran Mahkamah Konstitusi Dalam Pembangunan Hukum Nasional Dengan Model Preventive Review. Majalah Hukum Nasional, 49(1), 91-116. Retrieved from https://doi.org/10.33331/mhn.v49i1.94

Skripsi

Shalihah, Septiana Anifatus. 2018. Kedudukan Peraturan Mahkamah Agung Dalam Hierarki Peraturan Perundang-Undangan Di Indonesia (Studi tentang Implementasi PERMA Nomor 2 Tahun 2012 tentang Penyesuaian Batasan Tindak Pidana Ringan dan Jumlah Denda dalam KUHP di Pengadilan Negeri Kabupaten Gresik). Skripsi Sarjana, Universitas Islam Indonesia, Yogyakarta, Indonesia. Retrieved from https://help.uii.ac.id/bitstream/handle/123456789/6879/Septiana\%20An ifatus\%20S\%20\%2814410280\%29\%20Kedudukan\%20PERMA\%20dalam \%20Hierarki\%20Peraturan\%20Perundangundangan $\% 20$ di $\% 20$ Ind.pdf? sequence $=1 \&$ is Allowed $=\mathrm{y}$

Website

Bhakti, Ikrar Nusa. (2010). Power Tends to Corrupt. 7 January, 2020. http://lipi.go.id/berita/power-tends-to-corrupt/4869

Dariyanto, Erwin. (2018). Begini Alur Pembentukan Sebuah Undang-Undang. January 7, 2020. https://news.detik.com/berita/d-3882715/begini-alurpembentukan-sebuah-undang-undang 
(

Legal Perspective

7ग)徏 Volume 01, Issue 0, 2021, pp. 67-89

Zahra, Nindya Chairiunnisa., \& Sikumbang, Sony Maulana. (2014). Kewenangan Pembentukan Peraturan Menteri Sebagai Jenis Peraturan PerundangUndangan. January 5, 2020. http://lib.ui.ac.id/naskahringkas/201610//S58379-Nindya\%20Chairunnisa\%20Zahrariyadi 